\title{
Ecotourism revisited: Last twenty-five years
}

\author{
Abhinav Chandel ${ }^{1}$, Sita Mishra ${ }^{2}$ \\ e-mail: abhinav.chandel@gla.ac.in / smishra@imt.edu \\ ${ }^{1}$ GLA University, Mathura, India \\ ${ }^{2}$ Institute of Management Technology (IMT), Ghaziabad, India \\ Chandel, A., \& Mishra, S. (2016). Ecotourism revisited: Last twenty-five years. Czech Journal of Tourism, 5(2), $135-154$. \\ DOI: 10.1515/cjot-2016-0008.
}

\begin{abstract}
The concept of ecotourism evolves differently in developing and developed nations due to which the basic principles of ecotourism are in question. The existing literature on ecotourism suggests ambiguity in conceptual understanding of ecotourism. Due to this qualm, ecotourism is evolving into various forms. Different stakeholders with varying objectives related to ecotourism make it further difficult to form the consensus on what constitutes ecotourism. Without the clear understanding of ecotourism, it is difficult to evolve ethics on which the ecotourism principles are based. The focus of this research is to find out the principle components or themes of ecotourism using a content analysis for the development of ecotourism policy and applications. This study identified six key components of ecotourism which are widely accepted by researchers and could be used to shape the fundamental understanding of ecotourism. These themes are: (1) Nature oriented travel; (2) Support of conservation; (3) Learning and appreciation; (4) Socio-economic development of local area; (5) Support and respect for local culture and (6) Local people (area) participation.
\end{abstract}

\section{Keywords}

Ecotourism review, Content analysis, Ecotourism definition, Conservation, Nature-Based Tourism.

JEL classification: M31, L83, Q26 


\section{Introduction}

Ecotourism has been widely considered as a desirable form of tourism (Orams, 1995; Boyd \& Butler, 1996). It is observed as an approach of tourism which is nature-based, where some sought of learning and education is involved, which supports environmental conservation and focuses on the overall development of society. (Fennell, 1999; The International Ecotourism Society [TIES], 1998).

Ecotourism is interchangeably used with terms like sustainable tourism, responsible tourism, ethical tourism, ecological tourism, nature tourism, cultural tourism, heritage tourism (Blamey, 1997; Fennell, 1999; Weaver, 2001). This overlap with similar types of tourism makes it further difficult to understand ecotourism. To better understand ecotourism, it is imperative to look at the environmental conservation, local development and tourism from the holistic point of view (Scheyvens, 1999). It calls for a model where all stakeholders, specifically the government, NGOs, Tourists, Business Managers (Hoteliers, Travel agents) and, local people do not have conflicting objectives concerning ecotourism(Garrod, 2003). As it is widely accepted, profit is the bottom line of any business; this idea dominates the global market where tangible and intangible products related to tourism are seen as commodities (Harvey, 1998). The understanding of ecotourism has been further narrowed by introducing marketing oriented definitions and demand supply view (Franklin, 2003). In the early developmental stage of ecotourism the importance given to profit maximization was very high. Furthermore, literature recommends tourism product and services as commodities and therefore, definitions from both demand and supply perspectives are developed (Wearing et al., 2005).

It seems that stakeholders' focus on profit motive has compromised with components of ecotourism such as conservation and local area development. The commodification of ecotourism has led it to such a situation where it cannot be called even ecotourism. Thus, the aim of this paper is to present an analysis of the evolution of ecotourism concept and in addition, to identify various gaps in its conceptual understanding and operational applications.

\section{Theoretical background}

Ecotourism as a philosophy has been well accepted and appreciated among the scholars and industry (Tyler \& Dangerfield, 1999; Ross \& Wall, 1999; Goodwin, 1996). However, the problem lies in the application of ecotourism where its dimensions cannot be quantified for the sake of measurement and scaling (Ross \& Wall, 1999; Cater, 2004). Consensus has been reached on constituents, but it seems difficult to quantify them and hence to operationalize these components (Bottrill \& Pearce, 1995; Blamey, 1997; Diamantis, 1999). These widely accepted components or dimensions of ecotourism include non-consumptive nature of tourism, educational component, tourism in relatively undis-

turbed and under-visited areas, natural beauty, and cultural and historical importance of the place (Sirakaya et al., 1999). 
Although these dimensions have found a place in the ecotourism literature, the stakeholders' perspective varies a lot (Tsaur et al., 2006). In other words, we can say that 'realms' of the environmental, socioeconomic, cultural and technological worlds interfere (Zografos \& Oglethorpe, 2004). Firstly, "Non-Consumptive" component may indicate the sustainable and ethical consumption of resources but considering 'fishing' as an activity in ecotourism would present an ethical dilemma (Fennell, 2001). Even considering fishing as an activity may lead experts into another debate as to what extent this should be allowed (Buckley, 2005). Therefore, the issue of quantification needs to be explained. Secondly, considering the same situation, some species are labelled as vermin which leads to culling and poaching of these species, this again presents an ethical dilemma contradictory to the philosophy of ecotourism (Novelli et al., 2006). NGOs and other stakeholders related to nature conservation and wildlife protection disapprove of treating wildlife and other natural resources as commodities (King \& Stewart, 1996). Assuming education as an intrinsic component of ecotourism also poses another question. Merely taking tourists to a nature-based site does not fulfil tourist's motivations related to learning under education component. It is difficult to focus on content and magnitude of learning in ecotourism and retaining the entertainment value of the whole activity (Kimmel, 1999). Furthermore, any amount of tourism activity, whether conducted on a mass or small scale would lead to the degradation of an ecologically fragile zone. The environmental degradation presents another issue whether tourism should, or should not be carried out on undisturbed and under visited areas for the sake of economic activity (Dimanche \& Smith, 1996). The ecotourism principles also focus on preserving the cultural heritage of locals. It is observed that the interaction between the tourists and the locals over time may influence the lifestyle of local people. This impact results in local population losing pride in their aboriginal culture and values. They are also sometimes motivated to take up activities for economic gains (King \& Stewart, 1996; Carrier \& Macleod, 2005).

The conflicting motives of stakeholders mentioned above made researchers think about different approaches to the understanding of tourism (Jamal \& Stronza, 2009). Thus, minimalist and comprehensive approaches are evolved as two ways to describe two extreme poles of ecotourism. Proponents of the minimalist approach emphasize superficial learning and sustainable objectives which may vary in different settings. They also believe in maintaining the existing state of affairs, "Status-Quo", for a given site (Fennell \& Weaver, 2005). On the other hand, the comprehensive approach is more focused on a global approach to understand a general viewpoint on ecotourism. It involves indepth understanding of ecotourism leading to a transformation of individual's behaviour (Weaver, 2005; Hugo, 1999). Thus, we can identify four variables from both the minimalist and comprehensive approaches such as attractions, learning, sustainability and concomitant objectives. Both the minimalist and comprehensive approaches are different on the former three variables but agree on concomitant objectives. These concomitant objectives provide financial stability to the locals and a high level of satisfaction to tourists (Wearing, \& Neil, 2009). The present study is an extension of the previous study done by Weaver (2002) where the minimalist and comprehensive approaches are described as hard and soft ecotourism. 
The demand and supply perspectives are widely studied and accepted approaches on ecotourism. The supply perspective describes nature of ecotourism; venues and destinations; industry as main components of ecotourism (Sirakaya et al., 1999; Kontogeorgopoulos \& Chulikavit, 2010). Other themes such as ecotourism as a market segment, profiling of ecotourists, ecotourism interpretation and marketing come under the demand perspective (Carson \& Taylor, 2008). Some other areas of research on ecotourism focuses on themes such as institutions in ecotourism, impact on ecology, impact on culture and economy. These themes are discussed in relation to quality control and ethics (Weaver \& Lawton, 2007). In the last few decades, more emphasis has been put on researching understanding of the consumer behaviour in ecotourism and less attention on research issues like quality control, industry perspective of ecotourism, external environment, and institutions related to ecotourism (Black \& Crabtree, 2007; Weaver, 2001) .

Overall, discussions on principles of ecotourism and stakeholders' perspective of ecotourism have certain limitations which need to be clarified to make ecotourism practically viable.

\section{Methodology}

We have applied a content analysis to the definitions to pull out the common themes in ecotourism. The content analysis is a research instrument to make inferences based on the objective analysis by comparing, contrasting and categorizing (Schwandt, 2001).

\section{Collection of Samples}

The prominent definitions frequently cited in the ecotourism literature are collected and used for this study. A total of 42 most cited definitions (considering both demand and supply perspective) were selected and used for the analysis. Both online resources and books were searched to identify the definitions. The papers were reviewed from Scopus indexed journals to extract definitions of ecotourism. Important journals such as Annals of Tourism Research, Journal of Sustainable Tourism, Journal of Travel Research, Journal of Ecotourism, Tourism Management, and Current Issues in Tourism were reviewed.

\section{Analysis Criteria}

Definitions of ecotourism were objectively analysed, based on the themes emerging out of them. These themes were represented by keywords occurring in these definitions. The scope of the keyword's representation of a particular theme was decided on the basis of the literature review on ecotourism. Based on the analysis of these keywords, they were categorized under similar or separate themes. The analysis template was developed, based on the pilot survey. The pilot study focused on the preliminary analysis of the definitions and it was based on the critical review of literature (Donohoe \& Needham, 2006; 
Sirakaya et al., 1999; Fennell, 2003). We have identified 16 topics within the ecotourism definitions such as Nature Oriented Travel; Supports Conservation; Learning and Appreciation; Socio-Economic development of Local Area; Support and Respect for Local Culture; Local Area (people) Participation; Relatively Undisturbed Areas; Low negative impact; Ecologically Sustainable; Environmentally Responsible Tourism; Involves Wildlife Watching; Non-Consumptive; Small Scale; Travel to protected areas; Supports Human Rights; Volunteer Assistance.

The obtained data were tabulated in the form of thematic frequency of the observed definitions and percentage of their occurrence.

\section{Results}

A total of 42 ecotourism definitions mentioned in the ecotourism literature were identified over the past twenty-five years from 1990 to 2015 as depicted in Table 1. The emphasis on understanding ecotourism is very high because this industry is evolving into many different forms. The reason behind this is twofold. Firstly, due to the absence of an operational definition, the standards could not be laid down. Secondly, there is no consensus on conceptual understanding of ecotourism. Some forms are developing in synchronization with the ecotourism themes whereas others do not (Fennell, 2001).

Table 2 represents the components in the tabular form with the frequency of occurrence, percentage of occurrence and the rank order scale of the components. Figure 3 denotes the frequency distribution of components in the pictorial diagram. (Refer for Component variability). Figure 4 describes the model consisting of three stakeholders of ecotourism, specifically, 'Government,' 'Tourist' and 'NGO' focusing on one stakeholder 'locals.'

Table 1 Ecotourism definitions

\begin{tabular}{|c|l|}
\hline Code & \multicolumn{1}{|c|}{ Ecotourism definitions given by researchers } \\
\hline a & $\begin{array}{l}\text { Ziolkowski (1990) } \\
\text { "Low-impact tourism which focuses on experiencing the local culture and what it has to offer on its } \\
\text { unadulterated terms." }\end{array}$ \\
\hline b & $\begin{array}{l}\text { Boo (1991) } \\
\text { "Ecotourism / nature-oriented tourism refers to tourism to relatively undisturbed natural areas with } \\
\text { the specific objective of admiring, studying and enjoying the scenery and its flora and fauna." }\end{array}$ \\
\hline c & $\begin{array}{l}\text { Farrell and Runyan (1991) } \\
\text { "Focus on the environment in a special manner in which conservationists and tourist interests see } \\
\text { the mutual advantages of working together to preserve environmental quality while mutually pro- } \\
\text { tecting tourism. It focuses on nature conservation aided by cooperative strategies. It is a subset } \\
\text { of nature tourism taken a step farther, with nature and tourism considered equal partners. It is ex- } \\
\text { clusively purposeful and focused on the enhancement or maintenance of natural systems through } \\
\text { tourism." }\end{array}$ \\
\hline
\end{tabular}




\begin{tabular}{|c|c|}
\hline Code & Ecotourism definitions given by researchers \\
\hline$d$ & $\begin{array}{l}\text { Place (1991) } \\
\text { "Ecotourism is a gradual, small-scale approach, based on local savings and investment. Local par- } \\
\text { ticipation may provide the opportunity to integrate conservation and economic development for } \\
\text { park-based tourism development". }\end{array}$ \\
\hline e & $\begin{array}{l}\text { Boeger (1991) } \\
\text { "Ecotourism is environmentally sound tourism which respects the dignity and diversity of other } \\
\text { cultures as well as earth's renewable resources." }\end{array}$ \\
\hline$f$ & $\begin{array}{l}\text { Hunt (1992) } \\
\text { "Among the list of "neo-tourism" (new tourism initiatives, new players, new concerns, new ap- } \\
\text { proaches, new ideas and new terminology) activities is ecotourism. Eco/nature tourism is the result } \\
\text { of a long overdue recognition that tourism if properly developed and managed, can contribute to the } \\
\text { protection and preservation of unique natural and cultural environments, rather than exploit them. } \\
\text { Ecotourism advocates believe that there is a "kinder and gentler" tourism that does not necessarily } \\
\text { require extensive and intensive development or environmentally or socially degrading activities." }\end{array}$ \\
\hline g & $\begin{array}{l}\text { Williams (1992) } \\
\text { "Ecotourism entails "travel with substance" [and involves] traveling in relatively primitive and rural } \\
\text { circumstances, rustic accommodations, muddy trails, basic amenities, the pay-off being a stronger } \\
\text { appreciation and closer contact with wildlife, local culture and resource conservation issues." }\end{array}$ \\
\hline $\mathrm{h}$ & $\begin{array}{l}\text { Ecotourism Association of Australia (1992) } \\
\text { "Ecologically Sustainable tourism that fosters environmental and cultural understanding, apprecia- } \\
\text { tion and conservation." }\end{array}$ \\
\hline $\mathrm{i}$ & $\begin{array}{l}\text { Scace et al. (1992) } \\
\text { "An enlightening nature travel experience that contributes to conservation of the ecosystem while } \\
\text { respecting the integrity of the host communities." }\end{array}$ \\
\hline j & $\begin{array}{l}\text { Figgis (1992) } \\
\text { "Travel to remote or natural areas which aim to enhance understanding and appreciation of natural } \\
\text { environment and cultural heritage, avoiding damage or deterioration of the environment and the } \\
\text { experience to others" }\end{array}$ \\
\hline $\mathrm{k}$ & $\begin{array}{l}\text { Valentine (1993) } \\
\text { "Nature-based tourism that is ecologically sustainable and is based on relatively undisturbed natu- } \\
\text { ral areas, is non-damaging and non-degrading, contributes directly to the continued protection } \\
\text { and management of protected areas and subjected to adequate and appropriate management } \\
\text { regime." }\end{array}$ \\
\hline I & $\begin{array}{l}\text { Boyd and Butler (1993) } \\
\text { "A responsible nature travel experience, that contributes to the conservation of the ecosystem } \\
\text { while respecting the integrity of host communities and, where possible, ensuring that activities are } \\
\text { complementary or at least compatible, with existing resource-based uses present at the ecosys- } \\
\text { tem. Ecotourism is a form of tourism which fosters environmental principles, with an emphasis on } \\
\text { visiting and observing natural areas." }\end{array}$ \\
\hline
\end{tabular}




\begin{tabular}{|c|c|}
\hline Code & Ecotourism definitions given by researchers \\
\hline $\mathrm{m}$ & $\begin{array}{l}\text { Richardson (1993) } \\
\text { "Ecologically sustainable tourism in natural areas that interprets local environment and cultures, } \\
\text { furthers the tourists' understanding of them, fosters conservation and adds to the well-being of the } \\
\text { local people." }\end{array}$ \\
\hline $\mathrm{n}$ & $\begin{array}{l}\text { Tickell (1994) } \\
\text { "Travel to enjoy the world's amazing diversity of natural life and human culture without causing } \\
\text { damage to any of them." }\end{array}$ \\
\hline o & $\begin{array}{l}\text { Allcock and Evans-Smith (1994) } \\
\text { "Ecotourism is nature based tourism that involves education and interpretation of natural environ- } \\
\text { ment and is managed to be ecologically sustainable." }\end{array}$ \\
\hline$p$ & $\begin{array}{l}\text { Buckley (1994) } \\
\text { "Ecotourism might be defined as tourism that is nature based, environmentally educative, sustain- } \\
\text { ably managed and conservation supporting." }\end{array}$ \\
\hline$q$ & $\begin{array}{l}\text { Norris (1994) } \\
\text { "Clearly integrates both protection of resources with provision of local economic benefits." }\end{array}$ \\
\hline r & $\begin{array}{l}\text { Ballantine and Eagles (1994) } \\
\text { "A niche market of sustainable tourism. One of four non-consumptive forms of sustainable tourism. } \\
\text { Involves travel to discover and learn about wild natural environments. Has a long focus on learning } \\
\text { and discovering nature." }\end{array}$ \\
\hline $\mathrm{s}$ & $\begin{array}{l}\text { McCormick (1994) } \\
\text { "Purposeful travel to natural areas to understand the culture and natural history of the environment, } \\
\text { taking care not to alter the integrity of the ecosystem, while producing economic opportunities that } \\
\text { make the conservation of natural resources beneficial to local people." }\end{array}$ \\
\hline $\mathrm{t}$ & $\begin{array}{l}\text { Blamey (1995) } \\
\text { "An ecotourism experience is one in which an individual travels to what he/she considers to be } \\
\text { relatively undisturbed natural area and is more than } 40 \mathrm{kms} \text { from home, the primary intention being } \\
\text { to study, admire or appreciate the scenery and wild plants and animals as well as existing cultural } \\
\text { manifestations found in the area." }\end{array}$ \\
\hline u & $\begin{array}{l}\text { Ceballos-Lascurain (1996) } \\
\text { "Ecotourism is environmentally responsible travel and visitation to relatively undisturbed natural } \\
\text { areas, in order to enjoy and appreciate nature (and any accompanying cultural features - both past } \\
\text { and present) that promotes conservation, has low negative visitor impact, and provides for benefi- } \\
\text { cially active socio-economic involvement of local populations." }\end{array}$ \\
\hline $\mathrm{v}$ & $\begin{array}{l}\text { Wallace and Pierce (1996) } \\
\text { "Ecotourism is travel to relatively undisturbed natural areas for study, enjoyment or volunteer as- } \\
\text { sistance. It is travel that concerns itself with the flora, fauna, geology, and ecosystems of an area, } \\
\text { as well as the people (Caretakers) who live nearby, their needs, their culture, and their relationship } \\
\text { to the land. It views natural areas as "home to all of us" in a global sense ("Eco" meaning home) but } \\
\text { "home to nearby residents" specifically. It is envisioned as a tool for both conservation and sustain- } \\
\text { able development- especially in areas where local people are asked to forgo the consumptive use } \\
\text { of resources for others." }\end{array}$ \\
\hline
\end{tabular}




\begin{tabular}{|c|c|}
\hline Code & Ecotourism definitions given by researchers \\
\hline w & $\begin{array}{l}\text { Black (1996) } \\
\text { "An experience with a focus on the natural and cultural environment, ecologically sustainable activ- } \\
\text { ity, and activity with a predominant educative and interpretative programme, and an activity that } \\
\text { contributes to local community groups and projects and to the conservation of the surrounding } \\
\text { environment." }\end{array}$ \\
\hline $\mathrm{x}$ & $\begin{array}{l}\text { Brandon (1996) } \\
\text { "Environmentally responsible travel and visitation to relatively undisturbed natural areas, in order } \\
\text { to enjoy and appreciate nature that promotes conservation, has low negative visitor impact, and } \\
\text { provides for beneficially active socio-economic involvement of local populations." }\end{array}$ \\
\hline $\mathrm{y}$ & $\begin{array}{l}\text { Goodwin (1996) } \\
\text { "Low impact nature tourism which contributes to the maintenance of species and habitats either } \\
\text { directly through a contribution to conservation and/or indirectly by providing revenue to the local } \\
\text { community sufficient for local people, and therefore protect, their wildlife heritage area as a source } \\
\text { of income." }\end{array}$ \\
\hline$z$ & $\begin{array}{l}\text { Lindberg and McKercher (1997) } \\
\text { "Ecotourism is tourism and recreation which is both nature-based and sustainable. Concepts of } \\
\text { sustainability inevitably involve social, philosophical, and, political and environmental sustainabil- } \\
\text { ity." }\end{array}$ \\
\hline aa & $\begin{array}{l}\text { TIES (1998) } \\
\text { "Responsible travel to natural areas that conserves the environment and sustains the well-being of } \\
\text { local people. It is purposeful travel to natural areas to understand the culture and natural history of } \\
\text { the environment, taking care not to alter the integrity of the ecosystem while producing economic } \\
\text { opportunities that make the conservation of natural resources beneficial to local people." }\end{array}$ \\
\hline$a b$ & $\begin{array}{l}\text { Honey (2008) } \\
\text { "Ecotourism is travel to fragile, pristine and usually protected areas that strives to be low impact } \\
\text { and (usually) small scale. It helps educate the traveller; provides funds for conservation; directly } \\
\text { benefits the economic development and political empowerment of local communities; and fosters } \\
\text { respect for different cultures and for human rights." }\end{array}$ \\
\hline ac & $\begin{array}{l}\text { Embratur (1999) } \\
\text { "The segment of tourism activity which makes use of natural and cultural heritage in a sustainable } \\
\text { way, promotes its conservation and seeking to establish an environmental conscience through the } \\
\text { understanding of nature, and promoting the well-being of the involved population." }\end{array}$ \\
\hline ad & $\begin{array}{l}\text { Weaver (2001) } \\
\text { "Ecotourism is a form of tourism that fosters learning experiences and appreciation of the natural } \\
\text { Environment and enhances the cultural resource base of the destination and promotes the viability } \\
\text { of the operation." }\end{array}$ \\
\hline ae & $\begin{array}{l}\text { Fennell (2003) } \\
\text { "Ecotourism is a sustainable form of natural resource-based tourism that focuses primarily on ex- } \\
\text { periencing and learning about nature, and which is ethically managed to be low-impact, non-con- } \\
\text { sumptive and locally oriented (control, benefits and scale). It typically occurs in natural areas and } \\
\text { should contribute to the preservation of such areas." }\end{array}$ \\
\hline
\end{tabular}




\begin{tabular}{|c|c|}
\hline Code & Ecotourism definitions given by researchers \\
\hline af & $\begin{array}{l}\text { Nistoreanu et al. (2011) } \\
\text { "Ecotourism is a form of tourism where main motivation for tourists is the observation and apprecia- } \\
\text { tion of nature and local traditions related to nature and it must meet the following conditions: to con- } \\
\text { tribute to preserving and protecting nature, to use local human resources, to have an educational } \\
\text { experience, to cultivate respect for nature - awareness of tourists and local communities, to have } \\
\text { minimum negative impact on the natural environment and socio-cultural upliftment." }\end{array}$ \\
\hline ag & $\begin{array}{l}\text { Cristureanu C. (2006) } \\
\text { "Ecotourism is one of the forms of tourism developed in countries with natural and cultural potential } \\
\text { of a universal value." }\end{array}$ \\
\hline ah & $\begin{array}{l}\text { Donohoe (2011) } \\
\text { "Ecotourism includes community participation and benefits, environmental conservation, sustain- } \\
\text { able development, awareness/education, cultural sensitivity towards locals, ethics/responsibility } \\
\text { and cultural conservation." }\end{array}$ \\
\hline ai & $\begin{array}{l}\text { Sâmbotin et al. (2011) } \\
\text { "Ecotourism is a form of tourism developed in natural areas, whose goal is to acknowledge and to } \\
\text { appreciate nature and local culture, which includes conservation measures and ensure an active } \\
\text { involvement, generating benefits for the local population." }\end{array}$ \\
\hline aj & $\begin{array}{l}\text { Roxana (2012) } \\
\text { "Ecotourism should be seen in direct relation to nature conservation (protected Areas), with pres- } \\
\text { ervation of the authentic and involving local communities in stages of the process. Development } \\
\text { process is a lengthy process, which requires a sustained effort from all those involved but can bring } \\
\text { major benefits in the long term, contribute directly to the creation of "sustainable existing target } \\
\text { area"." }\end{array}$ \\
\hline ak & $\begin{array}{l}\text { Baral (2014) } \\
\text { "Ecotourism involves local capacity building, waste management, education and infrastructure } \\
\text { development. Building local capacity, facilitating self-organization and diversifying livelihoods can } \\
\text { enhance the resilience of ecotourism, sustaining stability and helping to deal with uncertainty." }\end{array}$ \\
\hline al & $\begin{array}{l}\text { Hunt et al. (2015) } \\
\text { "Ecotourism supports local communities economically by providing employment, improves their } \\
\text { quality of life (Social Upliftment) and focuses on environmental conservation. Local ownership is } \\
\text { high in ecotourism. Ecotourism negates the claims that it is simply a part of the "neoliberal conser- } \\
\text { vation toolkit" that cannot help but exacerbate the very inequalities it purports to address." }\end{array}$ \\
\hline am & $\begin{array}{l}\text { Carrascosa-López et al. (2014) } \\
\text { "Ecotourism must retain its essence which is its model of sustainability, preserving ecosystems and } \\
\text { satisfying local people improving their living conditions." }\end{array}$ \\
\hline an & $\begin{array}{l}\text { Silva (2015) } \\
\text { "Ecotourism is often viewed as a sustainable, non-consumptive strategy for the benefits of con- } \\
\text { servation and the local communities. It focuses on governance of resources, tourism's contribu- } \\
\text { tion to economic sustainability, cultural identity and social relations. Ecotourism is not a panacea } \\
\text { that always promotes biodiversity conservation and economic and socio-cultural sustainability for } \\
\text { the host communities but also the political, historical, economic and socio-cultural context of the } \\
\text { community involved is a key factor for understanding local agency and the local specific features } \\
\text { of ecotourism." }\end{array}$ \\
\hline
\end{tabular}




\begin{tabular}{|c|l|}
\hline Code & \multicolumn{1}{|c|}{ Ecotourism definitions given by researchers } \\
\hline ao & $\begin{array}{l}\text { Das and Chatterjee (2015) } \\
\text { "Ecotourism has proven to be an effective tool for environmental conservation. It is a community } \\
\text { based tourism which enables local people to augment their livelihoods security through employ- } \\
\text { ment in ecotourism-related activities. It involves empowering the community economically, socially } \\
\text { and politically. However it is causing detrimental conditions for the nature based destination." }\end{array}$ \\
\hline ap & $\begin{array}{l}\text { Cobbinah (2015) } \\
\text { "Ecotourism principles which are clear and widely promoted include environmental conservation } \\
\text { and education, cultural preservation, experience and economic benefits." }\end{array}$ \\
\hline
\end{tabular}

Source: authors' own

Variations were found in the themes of the ecotourism definitions (Table 2, Figure 1). The frequency or occurrence of these themes in the ecotourism definitions varied between 1 to 32 times. This result further supports the thematic variability identified by researchers (Bottrill \& Pearce, 1995; Fennell, 2001; Donohoe \& Needham, 2006). As compared to the earlier research, four strong themes emerge out of the content analysis, which represent more than $50 \%$ of the academic sample. The four developed themes from the observation of their frequency are (1) Nature-Oriented Travel (2) Supports Conservation (3) Learning and Appreciation (4) Socio-Economic Development of Local Area.

'Nature-oriented travel' has been recorded most frequently, occurring in the definitions 32 times out of 42 definitions making it almost 76\%. Similarly, 'Supports Conservation' has occurred 32 times in almost 76\% definitions. 'Learning and Education' and 'Socioeconomic development of local area' components appeared 24 times each, which makes it 57\%. Two other components which are 'Support and Respect for Local Culture' and 'Local Area (People) Participation' also appeared 18 and 14 times respectively, making them appear for $43 \%$ and $33 \%$ respectively. 'Relatively Undisturbed Area,' 'Low Negative Impact' and 'Ecologically Sustainable', are recorded ten times each, making it 24\% for all three. 'Environmentally Responsible Tourism' has been recorded five times, making it $12 \%$, 'Involves Wildlife Watching' and 'Non-Consumptive' have been recorded four times each with $10 \%$ occurrence. 'Small Scale' three times and $7 \%$ while 'Travel to Protected Areas,' 'Supports Human Rights' and 'Volunteer Assistance' have been recorded one time each, at almost $2 \%$ occurrence.

Since the four components appeared in more than $50 \%$ cases and two constituents which are cited in $43 \%$ and $33 \%$ cases, we considered these as major components. These themes are (1) Nature-Oriented Travel (2) Supports Conservation (3) Learning and Appreciation (4) Socio-Economic Development of Local Area (5) Support and Respect for Local Culture and (6) Local Area (People) Participation. 
Table 2 Occurrence of ecotourism issues among the definitions of ecotourism

\begin{tabular}{|c|c|c|c|c|c|c|c|c|c|c|c|c|c|c|c|c|c|c|c|c|c|c|c|}
\hline $\mathrm{S} . \mathrm{No}_{\mathrm{O}}$ & Items & $a$ & b & e & $d$ & $e$ & $f$ & $g$ & $h$ & $i$ & $j$ & $k$ & 1 & $m$ & $n$ & $o$ & $p$ & $q$ & $r$ & $s$ & $t$ & 4 & $v$ \\
\hline 1 & Nature Oriented Trafel & & $r$ & $r$ & & & $r$ & $r$ & & $r$ & $r$ & $r$ & $r$ & $r$ & $r$ & $r$ & $r$ & & $r$ & $r$ & $r$ & $r$ & $r$ \\
\hline 2 & Supports Conser子ation & & & $r$ & $r$ & $r$ & $r$ & $r$ & $r$ & $r$ & & & $r$ & $r$ & $r$ & $r$ & $r$ & $r$ & & $r$ & & $r$ & $r$ \\
\hline 3 & Leanning and Appreciation & $r$ & $r$ & & & & & $r$ & $r$ & & $r$ & & & $r$ & & $r$ & $r$ & & $r$ & $r$ & $r$ & $r$ & $r$ \\
\hline 4 & Socio Fconomic derelopment of Local Area & & & & $\checkmark$ & & & & & & & & & $\checkmark$ & & $\checkmark$ & & $\checkmark$ & & $\checkmark$ & & $r$ & \\
\hline 5 & Support and Respect for Local Culture & $r$ & & & & $r$ & $r$ & $r$ & & $r$ & $r$ & & $r$ & & $r$ & & & & & & $r$ & & $r$ \\
\hline 5 & Local Area (people) Participation & & & & $\checkmark$ & & & & & & & & & & & & & & & & & $\checkmark$ & $r$ \\
\hline 7 & Relatirely Undisturbed Areas & $\checkmark$ & $\checkmark$ & & & & $\checkmark$ & $\checkmark$ & & & & $r$ & & & & & & & & & $\checkmark$ & $r$ & $r$ \\
\hline 8 & Low negatife impact & $r$ & & & & & & & & & $r$ & $r$ & & & & & & & & & & $r$ & $r$ \\
\hline 9 & Fcologically Sustainable & & & & & & & & $\checkmark$ & & & $r$ & & $\checkmark$ & & & $\checkmark$ & & & & & & \\
\hline 10 & Enfironm entally responsible Tourism & & & & & $r$ & & & & & & & $r$ & & & & & & & & & $r$ & \\
\hline 11 & Infoltes Wildlife Watching & & $\checkmark$ & & & & & $\checkmark$ & & & & & & & & & & & & & $r$ & & $r$ \\
\hline 12 & Non Consumptife & & $\checkmark$ & & & & & & & & & & & & & & & & & & & & $r$ \\
\hline 13 & Small Scale & & & & $\checkmark$ & & & & & & & & & & & & & & & & & & \\
\hline 14 & Trafel to protected areas & & & & & & & & & & & & & & & & & & & & & & \\
\hline 15 & Supports Human Rights & & & & & & & & & & & & & & & & & & & & & & \\
\hline 16 & Volunteer Assistance & & & & & & & & & & & & & & & & & & & & & & $r$ \\
\hline
\end{tabular}

\begin{tabular}{|c|c|c|c|c|c|c|c|c|c|c|c|c|c|c|c|c|c|c|c|c|c|c|}
\hline S.No & Items & $w$ & $x$ & $y$ & $z$ & $a a$ & $a b$ & $a c$ & $a d$ & ae & af & $\operatorname{lgg}$ & aht & $a i$ & 믹 & $a k$ & al & $a m$ & ar & $\alpha \rho$ & $a p$ & $\begin{array}{c}\text { Total } \\
\text { Occurance }\end{array}$ \\
\hline 1 & Nature Oriented Trafel & 2 & & $r$ & $r$ & $r$ & & 2 & $r$ & $r$ & $r$ & $\checkmark$ & & $\checkmark$ & & $\checkmark$ & $\checkmark$ & & $\checkmark$ & $r$ & $\checkmark$ & 32 \\
\hline 2 & Supports Conserration & $r$ & $\checkmark$ & $r$ & $r$ & $r$ & $r$ & $r$ & & & $r$ & & $r$ & $\checkmark$ & $r$ & & $r$ & $\checkmark$ & $r$ & $r$ & $r$ & 32 \\
\hline 3 & Learning and Appreciation & $r$ & $r$ & & & & $r$ & $r$ & $r$ & $r$ & $r$ & & $r$ & $r$ & & $r$ & & & & & $r$ & 24 \\
\hline 4 & Socio Econonic defelopment of Lacal Area & $r$ & $r$ & $r$ & & $r$ & $r$ & $r$ & $r$ & $r$ & $r$ & & $r$ & $r$ & $r$ & $r$ & $r$ & $r$ & $\checkmark$ & $r$ & $r$ & 24 \\
\hline 5 & Support and Respect for Local Culture & $r$ & & & & & $r$ & & $\checkmark$ & & $r$ & $r$ & $r$ & $\checkmark$ & & & & & & & $\checkmark$ & 18 \\
\hline 5 & Lacal Area (people) Participation & & $r$ & & & & & & & $r$ & & & $r$ & $r$ & 8 & $r$ & $\checkmark$ & $r$ & $r$ & $r$ & 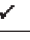 & 14 \\
\hline 7 & RelatiFely Undisturbed Areas & & $\checkmark$ & & & & $r$ & & & & & & & & & & & & & & & 10 \\
\hline 8 & Lorf negatife impact & & $r$ & $r$ & & & $r$ & & & $r$ & $r$ & & & & & & & & & & & 10 \\
\hline 9 & Feologicaly Sustainable & $r$ & & & $r$ & & & & & & & & $\checkmark$ & & & $\checkmark$ & & $r$ & $r$ & & & 10 \\
\hline 10 & Fnfironmentaly responsible Tourism & & $r$ & & & $r$ & & & & & & & & & & & & & & & & 5 \\
\hline 11 & Imrolfes Widdlife Watching & & & & & & & & & & & & & & & & & & & & & 4 \\
\hline 12 & Nan ConsumptiFe & & & & & & & & & $r$ & & & & & & & & & $\checkmark$ & & & 4 \\
\hline 13 & Small Seale & & & & & & $r$ & & & $r$ & & & & & & & & & & & & 3 \\
\hline 14 & Trarel to protected areas & & & & & & $r$ & & & & & & & & & & & & & & & 1 \\
\hline 15 & Supports Human Rights & & & & & & $r$ & & & & & & & & & & & & & & & 1 \\
\hline 16 & Folunteer Assistance & & & & & & & & & & & & & & & & & & & & & 1 \\
\hline
\end{tabular}

Notes: a: Ziolkowski (1990); b: Boo (1991); c: Farrell and Runyan (1991); d: Place (1991); e: Boeger (1991); f: Hunt (1992); g: Williams (1992); h: Ecotourism Association of Australia (1992); i: Scace et al. (1992); j: Figgis (1992); k: Valentine (1993); I: Boyd and Butler (1993); m: Richardson (1993); n: Tickell (1994); o: Allcock and Evens-Smith (1994); p: Buckley (1994); q: Norris (1994); r: Ballantine and Eagles (1994); s: McCormick (1994); t: Blamey (1995); u: Ceballos-Lascurain (1996); v: Wallace and Pierce (1996); w: Black (1996); x: Brandon (1996); y: Goodwin (1996); z: Lindberg and McKercher (1997); aa: TIES (1998); ab: Honey (2008); ac: Embratour (1999); ad: Weaver (2001); ae: Fennell (2003); af: Nistoreanu et al. (2011); ag: Cristureanu (2006); ah: Donohoe (2011); ai: Sâmbotin et al. (2011); aj: Roxana (2012);ak: Baral (2014); al: Hunt et al. (2015); am: Carrascosa-López et al. (2014); an: Silva (2015); ao: Das and Chatterjee (2015); ap: Cobbinah (2015).

Source: authors' own 
Figure 1 Frequencies of ecotourism themes

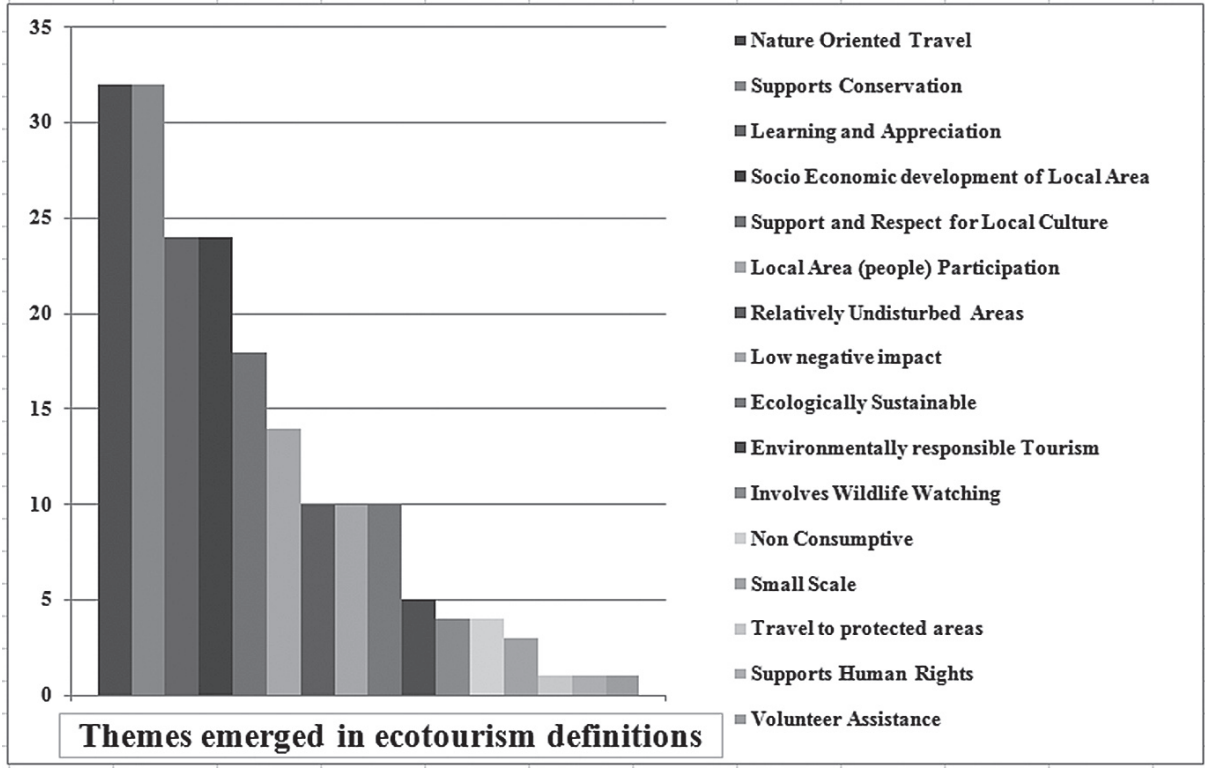

Source: authors' own

\section{Explanation of the themes}

Below there is an explanation of these important themes that emerged out of the content analysis of the ecotourism definitions.

Nature-Oriented Travel: Nature-oriented travel refers to the tourism taking place at nature based settings/destinations. These destinations are considered fragile due to their ecological sensitivity. The types of destinations covered under nature-oriented travel may include forests, wetlands, beaches, natural caves, deserts, mountains, or coral reefs.

Supports Conservation: Conservation refers to the protection of plants, animals, natural areas and structures from damaging effects of human activity. It aims at saving planet's non-renewable resources, flora and fauna.

Learning and Appreciation: It means that ecotourism is a form of tourism where learning and education are inherent. It involves learning about nature, wildlife, different habitats and environmental awareness about how we can contribute to the upkeep of the natural areas. Appreciating the nature in its original form is inherent.

Socio-Economic Development of Local Area: Tourism provides economic opportunities such as monetary benefits through transactions, job opportunities and social benefits such as health and hygiene. The socio-economic development of local population also involves political empowerment of local people. 
Support and Respect for Local Culture: This refers to (a) support (Monetary and Otherwise) for traditional practices such as dances and artworks so that they should not become extinct. (b) Local culture should not be influenced, undermined or contaminated by the tourist so that it should not lose its originality and hence value.

Local Area (People) Participation: It refers to an active participation of the host community or local people in the economic, social and political activity. These communities have a higher stake in ecotourism. Focus on community capacity building, self-organization and diversifying livelihood.

Relatively Undisturbed Areas: It refers to those areas which have a negligible human intervention. Ecological fragility is one of its important characteristics.

Low Negative Impact: Tourism must be conducted in a way which minimizes the negative effects on a given destination. High resource utilization, pollution, high carbon footprints and cultural degradation of aboriginal people are only a few examples.

Ecologically Sustainable: This refers to the capacity of the ecosystem to meet the present needs without compromising on future generations to meet their own. The ecological sustainability indicates using natural resources wisely in a short run to ensure their availability in the long run.

Environmentally Responsible Tourism: Indicates primarily the pro-environmental approach of stakeholders. Tourists to show responsible behaviour towards the environment, government to consider its importance while framing policies and business managers to follow the framed guidelines considering implementation.

Involves Wildlife Watching: Watching exotic species, both flora and fauna of the local area. Wildlife watching also involves learning and interpretation related to wildlife.

Non-Consumptive: Any Non-hunting or non-extractive use.

Small Scale: Supply side perspective indicating developing a systematic capacity to cater to small groups.

Travel to Protected Areas: Travel to legally protected areas. Nomenclature may vary such as National Parks, Wildlife sanctuaries, Biosphere Reserves and Game Reserves.

Supports Human Rights: This considers 'local population' as an important stakeholder in ecotourism and emphasizes protecting their legal rights.

Volunteer Assistance: Tourists are self-motivated to work as volunteers towards the cause of environmental protection, spreading awareness and upliftment of locals. 


\section{Discussions and Conclusion}

The literature review shows fairly a common understanding of components of ecotourism, however, an operational definition remains elusive. The definition of ecotourism must focus on developing parameters which help stakeholders to quantify them and help in estimating the number of all tourists who are 'ecotourists' (Lindberg, 1994). The definition of ecotourism given by NES indicates a theme mentioned as 'Nature-Based Experience'. It is important to understand what the 'Nature-Based Experience' constitutes? Ideally, its constitution must be in line with the ecotourism principles, but in order to achieve a higher level of customer satisfaction, we focus more on the 'Entertainment Value' while planning for the 'Nature Based Experience'. This shift leads to the deviation from the ecotourism principles. In addition, these experiences are difficult to assess in order to understand the level of customer satisfaction. Similarly, focusing on the sustainability theme, one may argue whether a 'Jeep Safari' through a forest can be qualified as an activity or a 'Back-Pack/Foot-Trail' can be considered as an activity. Secondly, how long (in term of time) an individual needs to be on a foot trail to be considered as an ecotourist or a non-ecotourist. Thirdly, it is difficult to differentiate an activity from the experience in ecotourism. For example, a walk in the forests would constitute experience or swimming in polluted streams and lakes. These observations made in the existing research suggest that it is useless to have a single definition of ecotourism which is applicable in all scenarios (Blamey, 1995). We need a definition of ecotourism which focuses on finding the standard indicators of ecotourism. These indicators must be in line with the principles of ecotourism and may serve as effective determinants in measuring the degree of ecotourism or determining the activities and experiences as ecotourism activity or general tourism.

The ecotourism definitions are presented on the continuum or range, which develops a better understanding of the indicators of ecotourism. This classification has helped the business managers and other stakeholders in developing the management strategies which attempt to understand motivations of tourists' experience from enjoyment to environmentally responsible behaviour (Orams, 1995). The strict definition of ecotourism is a mandatory requirement for a policy framework which relates to its legal implications. Finally, it is argued that different definitions of ecotourism are suited for different scenarios and circumstances. For example, the demand and supply perspective; or the comprehensive and minimalist approach. Due to these different perspectives and approaches, trade-off is required between the validity, reliability, and comparability of the ecotourism definitions.

The review of literature in ecotourism suggests that ecotourism should be separately viewed from the demand and supply side perspective. From the consumer's perspective, the past research suggests that tourist satisfaction should be achieved in order to maximize profits for other stakeholders or business managers. The conceptual understanding of ecotourism suggests that components of ecotourism such as nature-based, learning and education, (environmental, socio-culture and economic) and sustainability are more or less agreed upon in the past ecotourism research. Numerous profiling stud- 
ies are conducted in ecotourism where tourists are classified as 'Hard Ecotourists,' 'Soft Ecotourists,' depending on their tourist behaviour. The strong ecotourists may turn out to be a potential target market to the specially communicated programs and educational workshops conducted under these ecotourism programmes. It is widely observed that with tourists getting matured in their choices of ecotourism products and services, their satisfaction is also shifting to 'volunteering,' 'participating in community development,' 'donating,' or 'contributing in awareness programmes' . These changes in tourist behaviour indicate a positive shift of the inclusive development keeping 'Locals' central to the idea of ecotourism. In addition, a considerable difference is observed between the European and American consumers as compared to the Asian counterparts with reference to their ecological orientation (Wight, 1996). The public awareness is comparatively low in Asian countries as compared to other developed nations. The reasons could be a low education level or high population leading to high pressure and reliability on natural resources and processes.

The ecotourist satisfaction can be achieved by educating the tourist on the environmental sustainability goals such as protecting wildlife (flora and fauna) and other natural resources, waste minimization, litter drainage, water conservation, energy minimization, minimal impact on wildlife, increase in public environmental consciousness, or encouragement of donations. The sense of satisfaction for a tourist lies in the satisfaction that $\mathrm{s} /$ he gets with the contribution that $\mathrm{s} /$ he has made towards the community for educating them and the contribution that $\mathrm{s} /$ he has made in protecting wildlife or supporting conservation in any way.

Similarly, the socio-culture and economic sustainability goals could be incorporated under the given parameters. The socio-culture sustainability goals involve an active participation of 'the local community, promotion of local ownership (for example, souvenir shops), empowering of local people by building their confidence, appreciation of local culture, especially by tourists, enhancement of communication through interactions at different levels between the local community and tourists.

Out of sixteen themes that emerged in the content analysis, it can be observed that the frequency of occurrence of these themes is not uniform in definitions. The frequency of occurrence of four themes, as discussed earlier, is found in more than $50 \%$ of definitions. The repetitive occurrence of these themes suggests that these themes should hold greater importance in ecotourism literature. In addition to this, two themes 'Support and Respect for Local Culture' and 'Local Area Participation' have also occurred in the definitions accounting for $43 \%$ and $33 \%$ respectively. Hence, these six themes can be accepted as principles widely used by researchers in ecotourism. Based on this, the study concludes that the emerged six themes form the basic understanding of ecotourism. Due consideration must be given to these themes while formulating the policies in a given area or planning businesses related to ecotourism. The components, specifically, 'Socio-Economic Development of Local Area,' 'Support and Respect for Local Culture,' 'Supports Conservation' and 'Local Area (People) Participation cannot be included as the principles of ecotourism without an active participation of locals. In recent years, the use of keywords such as 'community-based tourism', 'cultural preservation,' 'economic sustainability of 
locals,' 'local capacity building' and 'local communities' has increased in the ecotourism definitions suggesting an equal emphasis on important stakeholders - 'locals or aboriginals.'

The content analysis also indicates that if we focus on the latest definitions of ecotourism, the theme of local area participation is consistent in appearance. The focus has lately shifted to the local capacity building and diversification of livelihoods. This shift to the local capacity building will help in enhancing the flexibility of ecotourism, sustaining stability and helping to deal with uncertainty.

The key areas identified which need attention are the economic sustainability goals, economic development of the local area, jobs for the local people, infrastructural development in other related industries, and the development of local infrastructure in general; local communities share in profits and promoting the consumption and production in the local area.

The present paper concludes that the ecotourism product must focus on the following salient features:

- Tourists appreciate it more when they are given the opportunity to directly and personally experience nature (focus on natural area);

- Assistance must be provided only when needed to enhance the experience (interpretation and education);

- Tourism should be in line with the best practices of environmental sustainability (environmentally sustainable practices);

- Generous contributions from different stakeholders towards the environmental conservation of the local area (contribution towards conservation);

- Local communities must benefit economically from independent activities of all stakeholders (benefit to local communities);

- Local cultural interpretation and upliftment are important. The local culture must be inclusive in the ecotourism philosophy (respect towards indigenous culture);

- From the business and profit making perspective, consumers' expectations must be consistently met (customer satisfaction);

- Tourism must be promoted in such a way that it does not lead to unrealistic expectations (responsible marketing).

\section{References}

Allcock, A., \& Evans-Smith, D. (1994). National ecotourism strategy. Canberra, Australia: Commonwealth Dept. of Tourism.

Ballantine, J. L., \& Eagles, P. F. J. (1994). Defining Canadian ecotourists. Journal of Sustainable Tourism, 2(4), 210-214. DOI: 10.1017/S0376892913000350.

Baral, N. (2014). Evaluation and resilience of ecotourism in the Annapurna Conservation Area, Nepal. Environmental Conservation, 41(1), 84-92. DOI: 10.1017/S0376892913000350. 
Black, R. (1996). Ecotourism, what does it really mean? Ranger: A journal for conservation managers, (34), 4-7.

Black, R., \& Crabtree, A. (Eds.). (2007). Quality assurance and certification in ecotourism. Wallingford, England/Cambridge, MA: CABI.

Blamey, R. K. (1995). The elusive market profile: Operationalising ecotourism. Paper presented at the Geography of Sustainable Tourism Conference, University of Canberra, ACT, Australia, September, 1995 (pp. 16-17). Canberra, Australia: Bureau of Tourism Research.

Blamey, R. K. (1997). Ecotourism: The search for an operational definition. Journal of Sustainable Tourism, 5(2), 109-130. DOI: 10.1080/09669589708667280.

Boeger, E. (1991). Ecotourism/the environment: or the immense potential and importance of ecotourism. Travel and Tourism Research Association Newsletter, 12(3), 5-6.

Boo, E. (1991). Planning for ecotourism. Parks, 2(3), 4-8.

Bottrill, C. G., \& Pearce, D. G. (1995). Ecotourism: Towards a key elements approach to operationalising the concept. Journal of Sustainable Tourism, 3(1), 45-54. DOI: 10.1080/09669589509510707.

Boyd, S. W., \& Butler, R. W. (1993). Review of the development of ecotourism with respect to identifying criteria for ecotourism for Northern Ontario. Report. Sault Ste. Marie, Ontario: Department of Natural Resources/Forestry Ministry of Natural Resources.

Boyd, S. W., \& Butler, R. W. (1996). Managing ecotourism: an opportunity spectrum approach. Tourism management, 17(8), 557-566. DOI: 10.1016/S0261-5177(96)00076-3.

Brandon, K. (1996). Ecotourism and conservation: A review ofkey issues. Working Paper 18285, The World Bank. Retrieved from http://documents.worldbank.org/curated/en/101351468767955325/ pdf/multi-page.pdf.

Buckley, R. (1994). A framework for ecotourism. Annals of Tourism Research, 21(3), 661-665. DOI: 10.1016/0160-7383(94)90126-0.

Buckley, R. (2005). In search of the narwhal: Ethical dilemmas in ecotourism. Journal of Ecotourism, 4(2), 129-134. DOI: 10.1016/S0261-5177(96)00076-3.

Carrascosa-López, C., Segarra-Oña, M., Peiró-Signes, A., \& De-Miguel-Molina, M. (2014). Ecotourism in Latin America, latest trends. In J. Mondéjar-Jiménez, G. Ferrari, M.D.V. Sagarra-Ona, \& A. Peiró-Signes (Eds.), Sustainable Tourism: A Collection of Tools and Best Practices (pp. 209-2018). Witney, England: Chartridge Books Oxford.

Carrier, J. G., \& Macleod, D. V. (2005). Bursting the bubble: The socio-cultural context of ecotourism. Journal of the Royal Anthropological Institute, 11(2), 315-334. DOI: 10.1111/j.14679655.2005.00238.x.

Carson, D. B., \& Taylor, A. J. (2008). Sustaining four wheel drive tourism in desert Australia: exploring the evidence from a demand perspective. The Rangeland Journal, 30(1), 77-83. DOI: 10.1071/RJ07036.

Cater, E. (2004). Ecotourism: Theory and Practice. In A. A. Lew, C. M. Hall, \& A. M. Williams (Eds.), A companion to tourism (pp. 484-497). Malden, MA/Oxford, UK/Carlton, Australia: Blackwell Publishing.

Ceballos-Lascurain, H. (1996). Tourism, ecotourism, and protected areas: The State of Nature-based Tourism around the World and Guidelines for Its Development. Gland, Switzerland: Union Internationale pour la Conservation de la Nature et de ses Ressources.

Cobbinah, P. B. (2015). Contextualising the meaning of ecotourism. Tourism Management Perspectives, 16, 179-189. DOI: 10.1016/j.tmp.2015.07.015.

Cristureanu, C. (2006). Strategies and transactions in international tourism. Bucharest, Romania: Beck. 
Das, M., \& Chatterjee, B. (2015). Ecotourism: A panacea or a predicament? Tourism Management Perspectives, 14, 3-16.

Diamantis, D. (1999). The concept of ecotourism: Evolution and trends. Current Issues in Tourism, 2(2-3), 93-122. DOI: 10.1080/13683509908667847.

Dimanche, F., \& Smith, G. (1996). Is ecotourism an appropriate answer to tourism's environmental concerns? Journal of Hospitality $\mathcal{E}$ Leisure Marketing, 3(4), 67-76. DOI: 10.1300/ J150v03n04_05.

Donohoe, H. M. (2011). Defining culturally sensitive ecotourism: a Delphi consensus. Current Issues in tourism, 14(1), 27-45. DOI: 10.1080/13683500903440689.

Donohoe, H. M., \& Needham, R. D. (2006). Ecotourism: The evolving contemporary definition. Journal of Ecotourism, 5(3), 192-210. DOI: 10.2167/joe152.0.

Ecotourism Association of Australia. (1992). What is Ecotourism? Retrieved from www.ecotourism. org.au.

Embratur. (1999). Estudos do Turismo Brsileiro. São Paulo, Brasil: Ministerio do Esporte Turismo.

Farrell, B. H., \& Runyan, D. (1991). Ecology and tourism. Annals of Tourism Research, 18(1), 26-40. DOI: 10.1016/0160-7383(91)90037-C.

Fennell, D. A. (1999). Ecotourism, an Introduction. New York: Routledge.

Fennell, D. A. (2001). A content analysis of ecotourism definitions. Current issues in tourism, 4(5), 403-421

Fennell, D. A. (2003). Ecotourism. London, UK: Routledge.

Fennell, D. A., \& Dowling, R. K. (Eds.). (2003). Ecotourism policy and planning. Wallingford, England/Cambridge, MA: CABI.

Fennell, D. A., \& Weaver, D. (2005). The ecotourium concept and tourism-conservation symbiosis. Journal of sustainable tourism, 13(4), 373-390. DOI: 10.1080/09669580508668563.

Figgis, P. J. (1992). Eco-Tourism Special Interest or Major Direction? Fitzroy, Australia: Australian Conservation Foundation.

Franklin, A. (2003). Tourism: An Itroduction. London/Thousand Oaks/New Delhi: Sage.

Garrod, B. (2003). Local participation in the planning and management of ecotourism: A revised model approach. Journal of Ecotourism, 2(1), 33-53. DOI: 10.1080/14724040308668132.

Goodwin, H. (1996). In pursuit of ecotourism. Biodiversity E Conservation, 5(3), 277-291. DOI: $10.1007 / \mathrm{BF} 00051774$.

Harvey, D. (1998). What's green and makes the environment go round. In F. Jameson \& M. Miyoshi (Eds.), The Cultures of Globalization (pp. 327-355). Durham: Duke University Press.

Honey, M. (2008). Ecotourism and sustainable development: Who owns paradise? Washington/Covelo/ London: Island Press.

Hugo, M. L. (1999). A comprehensive approach towards the planning, grading and auditing of hiking trails as ecotourism products. Current Issues in Tourism, 2(2-3), 138-173. $\quad$ DOI: $10.1080 / 13683509908667849$.

Hunt, C. A., Durham, W. H., Driscoll, L., \& Honey, M. (2015). Can ecotourism deliver real economic, social, and environmental benefits? A study of the Osa Peninsula, Costa Rica. Journal of Sustainable Tourism, 23(3), 339-357. DOI: 10.1080/09669582.2014.965176.

Hunt, J. D. (1992). Rural tourism: new focus on a traditional industry. Western Wildlands, 18(3), 2-3.

Jamal, T., \& Stronza, A. (2009). Collaboration theory and tourism practice in protected areas: Stakeholders, structuring and sustainability. Journal of Sustainable Tourism, 17(2), 169-189. DOI: $10.1080 / 09669580802495741$. 
Kimmel, J. R. (1999). Ecotourism as environmental learning. The Journal of Environmental Education, 30(2), 40-44. DOI: 10.1080/00958969909601869.

King, D. A., \& Stewart, W. P. (1996). Ecotourism and commodification: protecting people and places. Biodiversity Eं Conservation, 5(3), 293-305. DOI: 10.1007/BF00051775.

Kontogeorgopoulos, N., \& Chulikavit, K. (2010). Supply-side perspectives on ecotourism in Northern Thailand. International Journal of Tourism Research, 12(5), 627-641.

Lindberg, K. (1994). Quantifying Ecotourism-Are Reliable Statistics in Sight? The Ecotourism Society Newsletter, 4(2), 1-2.

Lindberg, K., \& McKercher, B. (1997). Ecotourism: a critical overview. Pacific Tourism Review, 1(1), $65-79$.

McCormick, K. (1994). Can ecotourism save the rainforests. Rainforest Action Network, 63.

Nistoreanu, P., Dorobantu, M. R., \& T,uclea, C. E. (2011). The trilateral relationship ecotourismsustainable tourism-slow travel among nature in the line with authentic tourism lovers. Revista de turism-studii si cercetari in turism, (11), 35-38.

Norris, R. (1994). Ecotourism in the national parks of Latin America. National Parks, 68(1-2), 33-37.

Novelli, M., Barnes, J.I., \& Humavindu, M.(2006). The other side of the ecotourism coin: consumptive tourism in Southern Africa. Journal of Ecotourism, 5(1-2), 62-79. DOI: 10.1080/14724040608668447.

Orams, M. B. (1995). Towards a more desirable form of ecotourism. Tourism management, 16(1), 3-8. DOI: 10.1016/0261-5177(94)00001-Q.

Place, S. E. (1991). Nature tourism and rural development in Tortuguero. Annals of Tourism Research, 18(2), 186-201. DOI: 10.1016/0160-7383(91)90003-T.

Rastogi, A., Badola, R., Hussain, S. A., \& Hickey, G. M. (2010). Assessing the utility of stakeholder analysis to Protected Areas management: The case of Corbett National Park, India. Biological Conservation, 143(12), 2956-2964. DOI: 10.1016/j.biocon.2010.04.039.

Richardson, J. A. (1993). Ecotourism E nature-based holidays. Marrickville, Australia: Choice Books. Ross, S., \& Wall, G. (1999). Ecotourism: towards congruence between theory and practice. Tourism Management, 20(1), 123-132. DOI: 10.1016/S0261-5177(98)00098-3.

Roxana, D. M. (2012). Considerations about Ecotourism and Nature-Based Tourism-Realities and Perspectives. International Journal of Academic Research in Economics and Management Sciences, 1(5), 215

Sâmbotin, D., Sâmbotin, A., Pătrăşcoiu, M., Coroian, A., \& Merce, I. I. (2011). Ecotourism - a model of sustainable development of tourism means. Lucrări Ştiințifice, 13(4), 221-226.

Scace, R. C., Grifone, E., \& Usher, R. G. (1992). Ecotourism in Canada. Consulting report prepared for the Canadian Environmental Advisory Council. Hull, Quebec: Minister of Supply and Services.

Scheyvens, R. (1999). Ecotourism and the empowerment of local communities. Tourism Management, 20(2), 245-249. DOI: 10.1016/S0261-5177(98)00069-7.

Schwandt, T.A. (2001). Dictionary of Qualitative Inquiry. London/Thousand Oaks/New Dheli: Sage.

Silva, L. (2015). How ecotourism works at the community-level: the case of whale-watching in the Azores. Current Issues in Tourism, 18(3), 196-211. DOI: 10.1080/13683500.2013.786027.

Sirakaya, E., Sasidharan, V., \& Sönmez, S. (1999). Redefining ecotourism: The need for a supplyside view. Journal of Travel Research, 38(2), 168-172. DOI: 10.1177/004728759903800210. The International Ecotourism Society [TIES]. (1998). What is Ecotourism? Retrieved from http:// www.ecotourism.org/what-is-ecotourism. 
Tickell, C. (1994). Foreword. In E. Carter \& G. Lowman (Eds.), Ecotourism: A Sustainable Option? Chichester/New York: Wiley.

Tsaur, S. H., Lin, Y. C., \& Lin, J. H. (2006). Evaluating ecotourism sustainability from the integrated perspective of resource, community and tourism. Tourism Management, 27(4), 640-653. DOI: 10.1016/j.tourman.2005.02.006.

Tyler, D., \& Dangerfield, J. M. (1999). Ecosystem tourism: A resource-based philosophy for ecotourism. Journal of sustainable tourism, 7(2), 146-158. DOI: 10.1080/09669589908667332.

Valentine, P. S. (1993). Ecotourism and nature conservation: A definition with some recent developments in Micronesia. Tourism Management, 14(2), 107-115. DOI: 10.1016/0261-5177(93)90043-K.

Wallace, G. N., \& Pierce, S. M. (1996). An evaluation of ecotourism in Amazonas, Brazil. Annals of Tourism Research, 23(4), 843-873. DOI: 10.1016/0160-7383(96)00009-6.

Wearing, S., \& Neil, J. (2009). Ecotourism: impacts, potentials and possibilities? Kidlington, UK: Elsevier Butterworth-Heinemann.

Wearing, S., McDonald, M., \& Ponting, J. (2005). Building a decommodified research paradigm in tourism: The contribution of NGOs. Journal of Sustainable Tourism, 13(5), 424-439. DOI: $10.1080 / 09669580508668571$.

Weaver, D. B. (2002). The evolving concept of ecotourism and its potential impacts. International Journal of Sustainable Development, 5(3), 251-264. DOI: 10.1504/IJSD.2002.003753.

Weaver, D. B. (2005). Comprehensive and minimalist dimensions of ecotourism. Annals of Tourism Research, 32(2), 439-455. DOI: 10.1016/j.annals.2004.08.003.

Weaver, D. B. (Ed.). (2001). The Encyclopedia of Ecotourism. Wallingford, UK/Cambridge, MA: CABI.

Weaver, D. B., \& Lawton, L. J. (2007). Twenty years on: The state of contemporary ecotourism research. Tourism Management, 28(5), 1168-1179. DOI: 10.1016/j.tourman.2007.03.004.

Wight, P. A. (1996). North American ecotourists: Market profile and trip characteristics. Journal of Travel Research, 34(4), 2-10.

Williams, P. W. (1992). A local framework for ecotourism development. Western Wildlands, 18(3), 14-19

Ziolkowski, H. (1990). Ecotourism: Loving nature on its own terms. Calypsl Log, 3, 16-19.

Zografos, C., \& Oglethorpe, D. (2004). Multi-criteria analysis in ecotourism: using goal programming to explore sustainable solutions. Current Issues in Tourism, 7(1), 20-43. DOI: $10.1080 / 13683500408667971$. 